\title{
MOTERŲ MIOKARDO INFARKTO KLINIKINĖS SIMPTOMATIKOS IR BAIGČIŲ YPATUMAI
}

\author{
Žaneta Petrulionienè $\dot{1}^{1,2}$, Pranas Šerpytis ${ }^{1,2}$, Dovilè Jančauskaite் $\dot{e}^{3}$, Urtė Gargalskaitė ${ }^{1,3}$, \\ Brigita Brazauskaitè ${ }^{1,3}$, Antanas Strazdas ${ }^{1,3}$ \\ ${ }^{I}$ Vilniaus universiteto ligoninès Santariškiu klinikos, ${ }^{2}$ Vilniaus universiteto ligoninès \\ Santariškiu kliniku Kardiologijos ir angiologijos centras, \\ ${ }^{3}$ Vilniaus universiteto Medicinos fakultetas
}

Raktažodžiai: miokardo infarktas, rizikos veiksniai, moterys, simptomai.
Santrauka
Darbo tikslas. Nustatyti jaunesnių (iki $55 \mathrm{~m}$.) ir vy- resnių ( $\geq 55 \mathrm{~m}$.) moterų, sirgusių ūminiu miokardo infarktu, simptomų, gretutinių ligų, rizikos veiksnių ir baigčių skirtumus.
Tyrimo medžiaga ir metodai. Atlikta retrospektyvi- nè pacienčių, gydytų $2012 \mathrm{~m}$. dẻl ūminio miokardo infarkto, ligos istorijų analizè. Ištirtos 473 pacien- tès, kurios buvo suskirstytos ị grupes pagal amžių: iki $55 \mathrm{~m}$., $55 \mathrm{~m}$. ir vyresnès. Pirmają grupę sudarè 37 moterys, vyresniujų grupę -436 .
Rezultatai. Pacienčių amžiaus vidurkis $72,3 \pm 11,07$ m. Miokardo infarktas su ST segmento pakilimu di- agnozuotas $54,3 \%$, iš jų Q+ 70,4\%, Q- 29,6\% (p < $0,001)$, be ST pakilimo 45,7\%, iš jų Q+ 6,5\%, Q- $93,5 \%(p<0,001)$, tarp amžiaus grupių statistiš- kai reikšmingo skirtumo nerasta. Pirmine arterine hipertenzija (PAH) iki $55 \mathrm{~m}$. sirgo 73\% (I laipsnio $2,7 \%$, II $59,5 \%$, III $10,8 \%$ ), $\geq 55 \mathrm{~m}$. - sirgo $92,7 \%$ (I laipsnio 0,7\%, II 86\%, III 6\%), (p < 0,001). Cu- kriniu diabetu iki $55 \mathrm{~m}$. sirgo $13,5 \%$ (I tipo 5,4\%, II tipo $8,1 \%$ ), $\geq 55 \mathrm{~m}$. - sirgo $23,9 \%$ (I tipo $0,3 \%$, II tipo $23,6 \%),(p<0,001)$. Širdies ritmo sutriki- mai dažniau nustatyti moterims $\geq 55 \mathrm{~m}$. $(32,8 \%)$, $(\mathrm{p}=0,006)$. Tarp moterų, kurioms nustatyti širdies ritmo sutrikimai, persistuojantis prieširdžiu virpè- jimas nustatytas $27,2 \%$, permanentinis prieširdžių virpejjimas $18,4 \%$, skilvelių virpejjimas $4,1 \%$ (visų $\mathrm{p}<0,001)$. Miokardo infarktu ankščiau persirgo iki $55 \mathrm{~m} .5,4 \%, 55 \mathrm{~m}$. ir vyresnès $20 \%(\mathrm{p}=0,03)$. Skaus- mas plito ị kairę ranką dažniau jaunesnèms $(27 \%)$, $(p=0,047)$. Silpnumą juto iki 55 m. 18,9\%, $\geq 55$ m.

$38,5 \%$, ( $\mathrm{p}=0,018)$. Letali baigtis sudare $6,8 \%$, visos mirusios pacientès buvo vyresnès nei $55 \mathrm{~m}$. Mirusioms Killip IV buvo nustatyta 78,1\% $(\mathrm{p}<0,001)$. Išvados. Vyresnès moterys ( $\geq 55 \mathrm{~m}$.), gydomos dèl ūminio miokardo infarkto, dažniau serga II laipsnio $\mathrm{PAH}$, turi širdies ritmo sutrikimų, persirgusios miokardo infarktu, jaučia silpnumą, tačiau jaunesnès dažniau serga I tipo cukriniu diabetu, būdingas skausmo plitimas ị kairę ranką. Nustatyta Killip IV lemia didesnị letalumą.

\section{İvadas}

Kardiovaskulinès ligos išlieka pagrindinė moterų mirties priežastis. Dèl šių ligų Europoje kasmet miršta 54\% visų moterų [1]. Lietuvoje šis rodiklis kiek didesnis 65,0\%. 2013 m. moteru mirtingumas nuo kraujotakos sistemos ligų buvo 843,9/100 000 moterų. Lyginant su 2012 $\mathrm{m}$. šis rodiklis padidejjo $2,4 \%$. Tarp $16-64 \mathrm{~m}$. amžiaus 2013 m. mirusių moterų dažniausia mirties priežastis buvo išeminè širdies liga (IŠL) (11\%) [2]. Europoje šis rodiklis skiriasi nedaug $-2012 \mathrm{~m} .10 \%$ moterų iki $65 \mathrm{~m}$. mirè dèl IŠL [3]. Nuo $2002 \mathrm{~m}$. Lietuvoje pastebimas moterų iki 65 m. mirtingumo nuo išeminès širdies ligos augimas [4].

Miokardo infarktas moterims pasireiškia vyresniame amžiuje negu vyrams $[5,6]$. Moterys prieš menopauzę turi mažesnę riziką sirgti hipertenzija ir kardiovaskulinėmis ligomis negu to paties amžiaus vyrai. Tai rodo, kad lytiniai hormonai (estrogenai) atlieka kardioprotekcini vaidmeni [7]. Tačiau tyrimų duomenys teigia, kad didejja jaunų moterų, sergančių ūminiu miokardo infarktu, skaičius ir hospitalizacijų dažnis $[8,9]$. Jaunoms moterims prieš menopauzę dažniau paplitusios nepalankios baigtys negu vyrams. Pastaruosius dvidešimt metų mokslininkų susidomejjimas moterų išemine širdies liga žymiai išaugo [10]. Geresnis procesų, mechanizmų ir simptomų pasireiškimo moteriš- 
kajai lyčiai supratimas galètų pagerinti miokardo infarkto prevenciją ir sumažinti sergamumą išemine širdies liga.

Šio tyrimo tikslas nustatyti jaunesnių (iki $55 \mathrm{~m}$.) ir vyresnių ( $\geq 55 \mathrm{~m}$.) moterų, sirgusių ūminiu miokardo infarktu, simptomų, gretutinių ligų, rizikos veiksnių ir baigčių skirtumus.

\section{Tyrimo medžiaga ir metodai}

Atlikta retrospektyvinė pacienčių, gydytų $2012 \mathrm{~m}$. Vilniaus universiteto ligoninès Santariškių klinikose dèl ūminio miokardo infarkto, ligos istorijų analizè. Ištirtos 473 pacientès, kurios buvo suskirstytos ị grupes pagal amžių: iki $55 \mathrm{~m}$., $55 \mathrm{~m}$. ir vyresnès. Dèl pacienčių menopauzès pradžios duomenų trūkumo pasirinkta vidutinè menopauzès pradžia - $55 \mathrm{~m}$. amžiaus riba, skirstant tiriamąsias i grupes. Pirmają amžiaus grupę ( $<55 \mathrm{~m}$.) sudare $37(7,8 \%)$ pacientès, vyresniųjų grupę ( $\geq 55 \mathrm{~m}$.) - $436(92,2 \%)$. Duomenys apdoroti Microsoft Excel ir SPSS programomis. Lyginant kiekybinius kintamuosius tarp dviejų grupių naudotas t-testas, kategorinių kintamujų palyginimui taikytas chi kvadrato testas. Kiekybiniams kintamiesiems pateikti vidurkiai, standartiniai nuokrypiai. Kategorinių kintamujų pateikti duomenų absoliutūs skaičiai $(\mathrm{N})$, procentinè jų išraiška (proc.) ir dažnių lentelès. Rezultatai vertinti statistiškai patikimais, kai $\mathrm{p}<0,05$.

\section{Rezultatai}

Tirtų pacienčių amžiaus vidurkis $72,3 \pm 11,07 \mathrm{~m}$. Miokardo infarktas su ST pakilimu (STEMI) diagnozuotas 257 $(54,3 \%)$, iš jų Q+ $181(70,4 \%)$, Q- $76(29,6 \%)(p<0,001)$, be ST pakilimo (NSTEMI) - $216(45,7 \%)$, iš jų Q+ 14 $(6,5 \%)$, Q- $202(93,5 \%)(\mathrm{p}<0,001)$, tarp amžiaus grupių

1 lentelè. Gretutinès ir persirgtos ligos

\begin{tabular}{|c|c|c|c|c|c|c|c|}
\hline \multirow[b]{2}{*}{ Požymis } & \multicolumn{2}{|c|}{$\begin{array}{c}\text { Iš viso } \\
(\mathrm{N}=473)\end{array}$} & \multicolumn{2}{|c|}{$\begin{array}{c}\text { Iki } 55 \text { m. } \\
(N=37)\end{array}$} & \multicolumn{2}{|c|}{$\begin{array}{c}55 \mathrm{~m} . \\
\text { ir vyresnès } \\
(\mathrm{N}=436)\end{array}$} & \multirow[b]{2}{*}{ p } \\
\hline & $\mathbf{N}$ & proc. & $\mathbf{N}$ & proc. & $\mathbf{N}$ & proc. & \\
\hline Pirminė arterinė hipertenzija & 431 & 91,1 & 27 & 73,0 & 404 & 92,7 & 0,000 \\
\hline Dislipidemija & 290 & 61,3 & 27 & 73,0 & 263 & 60,3 & 0,129 \\
\hline Cukrinis diabetas & 109 & 23 & 5 & 13,5 & 104 & 23,9 & 0,152 \\
\hline Širdies ritmo sutrikimai & 147 & 31,1 & 4 & 10,8 & 143 & 32,8 & 0,006 \\
\hline Kitos endokrininės ligos & 43 & 9,1 & 6 & 16,2 & 37 & 8,5 & 0,116 \\
\hline Anemija & 31 & 6,6 & 2 & 5,4 & 29 & 6,7 & 0,769 \\
\hline $\begin{array}{l}\text { Sisteminės jungiamojo } \\
\text { audinio ligos }\end{array}$ & 16 & 3,4 & 2 & 5,4 & 14 & 3,2 & 0,478 \\
\hline Inkstų funkcijos sutrikimas & 36 & 7,6 & 1 & 2,7 & 35 & 8,0 & 0,497 \\
\hline Persirgtas miokardo infarktas & 89 & 18,8 & 2 & 5,4 & 87 & 20,0 & 0,030 \\
\hline Persirgtas insultas & 73 & 15,4 & 3 & 8,1 & 70 & 16,1 & 0,199 \\
\hline
\end{tabular}

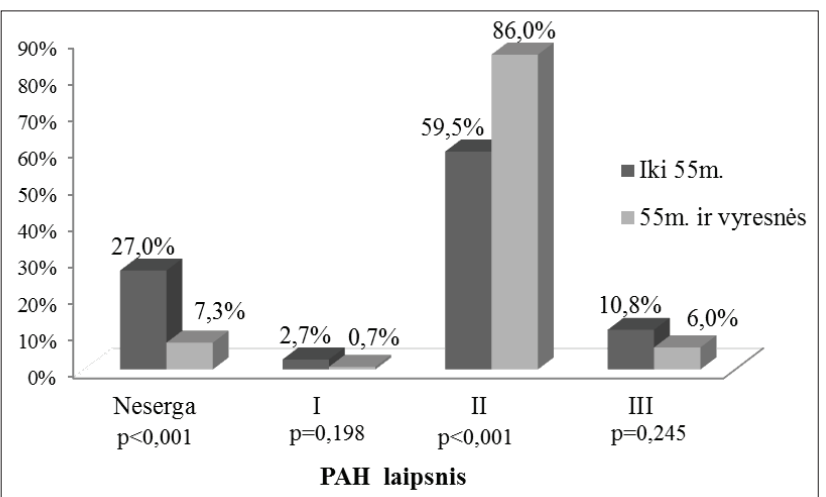

1 pav. Sergančiujų pirmine arterine hipertenzija pasiskirstymas pagal amžiaus grupes

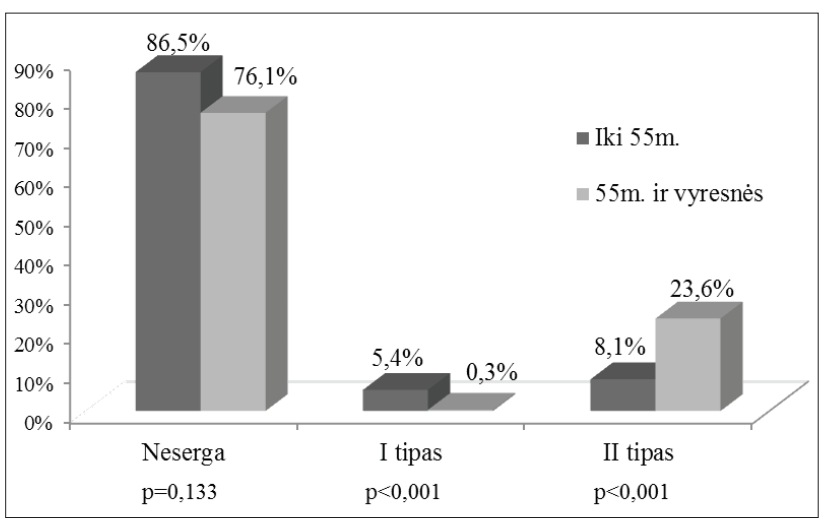

2 pav. Sergančiujų cukriniu diabetu pasiskirstymas pagal amžiaus grupes

statistiškai reikšmingo skirtumo nerasta.

$431(91,1 \%)$ sirgo pirmine arterine hipertenzija, vyresnès moterys dažniau negu jaunesnès (1 lentelè). Taip pat moterys $\geq 55 \mathrm{~m}$. dažniau sirgo II laipsnio PAH, o tarp jaunesnių sergančiųjų PAH buvo mažiau $(\mathrm{p}<0,001)$. Sergančiujų PAH pasiskirstymas pagal amžiaus grupes pateikiamas 1 paveiksle.

Dislipidemija diagnozuota 290 (61,3\%) moterų, iš jų $273(57,6 \%)$ diagnozuota atlikus lipidogramą, $17(3,6 \%)$ žinoma iš anamnezès. Statistiškai patikimo skirtumo tarp amžiaus grupių nerasta, tačiau matoma tendencija, kad moterys iki $55 \mathrm{~m}$. sirgo dažniau negu vyresnès.

$109(23 \%)$ moterų sirgo cukriniu diabetu, iki 55 m. - $5(13,5 \%), \geq 55$ m. - 104 (23,9\%). Jaunesnès moterys dažniau sirgo I tipo cukriniu diabetu, palyginus su vyresnių pacienčiu grupe, o $55 \mathrm{~m}$. ir vyresnès dažniau - II tipo cukriniu diabetu $(\mathrm{p}<0,001)$ (2 pav.).

Širdies ritmo sutrikimai dažniau nustatyti vyres- 
2 lentelè. Skausmo pobūdis krūtinèje pagal amžiaus grupes

\begin{tabular}{|c|c|c|c|c|c|c|c|}
\hline \multirow[t]{2}{*}{ Simptomas } & \multicolumn{2}{|c|}{$\begin{array}{c}\text { Iš viso } \\
(N=473)\end{array}$} & \multicolumn{2}{|c|}{$\begin{array}{l}\text { Iki } 55 \text { m. } \\
(\mathbf{N}=\mathbf{3 7})\end{array}$} & \multicolumn{2}{|c|}{$\begin{array}{c}55 \mathrm{~m} . \text { ir } \\
\text { vyresnès } \\
(\mathrm{N}=436)\end{array}$} & \multirow[t]{2}{*}{$\mathbf{p}$} \\
\hline & $\mathbf{N}$ & proc. & $\mathbf{N}$ & proc. & $\mathbf{N}$ & proc. & \\
\hline $\begin{array}{l}\text { Skausmas už } \\
\text { krūtinkaulio }\end{array}$ & 415 & 87,7 & 36 & 97,3 & 379 & 86,9 & 0,065 \\
\hline Spaudimas & 147 & 31,1 & 12 & 32,4 & 135 & 31,0 & 0,853 \\
\hline Maudimas & 54 & 11,4 & 5 & 13,5 & 49 & 11,2 & 0,676 \\
\hline $\begin{array}{l}\text { Deginimo } \\
\text { jausmas }\end{array}$ & 23 & 4,9 & 2 & 5,4 & 21 & 4,8 & 0,873 \\
\hline Diskomfortas & 18 & 3,8 & 2 & 5,4 & 16 & 3,7 & 0,596 \\
\hline $\begin{array}{l}\text { Duriantis } \\
\text { skausmas }\end{array}$ & 16 & 3,4 & 2 & 5,4 & 14 & 3,2 & 0,478 \\
\hline $\begin{array}{l}\text { Plěšiantis } \\
\text { skausmas }\end{array}$ & 7 & 1,5 & 2 & 5,4 & 5 & 1,1 & 0,039 \\
\hline Sunkumas & 4 & 0,8 & 0 & 0,0 & 4 & 0,9 & 0,558 \\
\hline
\end{tabular}

3 lentelè. Skausmo plitimas pagal amžiaus grupes

\begin{tabular}{|c|c|c|c|c|c|c|c|}
\hline \multirow[t]{2}{*}{ Simptomas } & \multicolumn{2}{|c|}{$\begin{array}{c}\text { Iš viso } \\
(\mathrm{N}=473)\end{array}$} & \multicolumn{2}{|c|}{$\begin{array}{c}\text { Iki } 55 \text { m. } \\
(\mathbf{N}=37)\end{array}$} & \multicolumn{2}{|c|}{$\begin{array}{c}55 \text { m. ir } \\
\text { vyresnès } \\
(\mathrm{N}=436)\end{array}$} & \multirow[t]{2}{*}{ p } \\
\hline & $\mathbf{N}$ & proc. & $\mathbf{N}$ & proc. & $\mathbf{N}$ & proc. & \\
\hline I kairę ranką & 74 & 15,6 & 10 & 27,0 & 64 & 14,7 & 0,047 \\
\hline I tarpumentę & 51 & 10,8 & 3 & 8,1 & 48 & 11,0 & 0,585 \\
\hline I dešinę ranką & 36 & 7,6 & 4 & 10,8 & 32 & 7,3 & 0,445 \\
\hline I kaklą & 28 & 5,9 & 4 & 10,8 & 24 & 5,5 & 0,191 \\
\hline I gerklę & 22 & 4,7 & 4 & 10,8 & 18 & 4,1 & 0,064 \\
\hline I kairị petị & 20 & 4,2 & 2 & 5,4 & 18 & 4,1 & 0,711 \\
\hline I epigastriumą & 19 & 4,0 & 2 & 5,4 & 17 & 3,9 & 0,654 \\
\hline $\begin{array}{l}\text { I } \text { apatinị } \\
\text { žandikaulị }\end{array}$ & 13 & 2,7 & 2 & 5,4 & 11 & 2,5 & 0,303 \\
\hline I dešinị petị & 10 & 2,1 & 0 & 0,0 & 10 & 2,3 & 0,352 \\
\hline I kairę mentị & 6 & 1,3 & 1 & 2,7 & 5 & 1,1 & 0,417 \\
\hline I dešinę mentị & 3 & 0,6 & 0 & 0,0 & 3 & 0,7 & 0,613 \\
\hline
\end{tabular}

nėms pacientėms (1 lentelè). Tarp moterų, kurioms nustatyti širdies ritmo sutrikimai, persistuojantis prieširdžių virpejjimas nustatytas $40(27,2 \%)$, permanentinis prieširdžių virpejimas $27(18,4 \%)$, skilvelių virpejjimas $6(4,1 \%)$ (visų $\mathrm{p}<0,001)$, pusei pacienčių nustatyti tokie ritmo sutrikimai kaip paroksizminis prieširdžių virpejjimas, AV blokada, kairès ar dešinès Hiso pluošto kojytès blokada, prieširdinès, supraventrikulinès ir skilvelinès ekstrasistolès (3pav.).

Miokardo infarktu ankščiau persirgo: iki $55 \mathrm{~m} .2$ $(5,4 \%), 55 \mathrm{~m}$. ir vyresnès $-87(20 \%),(\mathrm{p}=0,03)$. Ankščiau
4 lentelè. Kitų simptomų dažnis pagal amžiaus grupes

\begin{tabular}{|c|c|c|c|c|c|c|c|}
\hline \multirow{2}{*}{ Simptomas } & \multicolumn{2}{|c|}{$\begin{array}{c}\text { Iš viso } \\
(\mathrm{N}=473)\end{array}$} & \multicolumn{2}{|c|}{$\begin{array}{c}\text { Iki } 55 \text { m. } \\
(N=37)\end{array}$} & \multicolumn{2}{|c|}{$\begin{array}{c}55 \mathrm{~m} . \text { ir } \\
\text { vyresnès } \\
(\mathrm{N}=436)\end{array}$} & \multirow{2}{*}{$\mathbf{p}$} \\
\hline & $\mathbf{N}$ & proc. & $\mathbf{N}$ & proc. & $\mathbf{N}$ & proc. & \\
\hline Silpnumas & 175 & 37,0 & 7 & 18,9 & 168 & 38,5 & 0,018 \\
\hline Dusulys & 71 & 15,0 & 6 & 16,2 & 65 & 14,9 & 0,831 \\
\hline Pykinimas & 54 & 11,4 & 5 & 13,5 & 49 & 11,2 & 0,676 \\
\hline Prakaitavimas & 43 & 9,1 & 4 & 10,8 & 39 & 8,9 & 0,705 \\
\hline Oro trūkumas & 37 & 7,8 & 1 & 2,7 & 36 & 8,3 & 0,227 \\
\hline $\begin{array}{l}\text { Sąmonės } \\
\text { praradimas }\end{array}$ & 33 & 7,0 & 1 & 2,7 & 32 & 7,3 & 0,228 \\
\hline Vèmimas & 26 & 5,5 & 3 & 8,1 & 23 & 5,3 & 0,468 \\
\hline Širdies plakimai & 21 & 4,4 & 2 & 5,4 & 19 & 4,4 & 0,766 \\
\hline $\begin{array}{l}\text { Kairès rankos } \\
\text { tirpimas }\end{array}$ & 16 & 3,4 & 2 & 5,4 & 14 & 3,2 & 0,478 \\
\hline Galvos svaigimas & 14 & 3,0 & 0 & 0,0 & 14 & 3,2 & 0,269 \\
\hline $\begin{array}{l}\text { Spaudimo } \\
\text { jausmas gerklèje }\end{array}$ & 5 & 1,1 & 0 & 0,0 & 5 & 1,1 & 0,513 \\
\hline Galvos skausmas & 5 & 1,1 & 0 & 0,0 & 5 & 1,1 & 0,513 \\
\hline Šalčio krètimas & 5 & 1,1 & 1 & 2,7 & 4 & 0,9 & 0,308 \\
\hline Kosulys & 4 & 0,8 & 0 & 0,0 & 4 & 0,9 & 0,558 \\
\hline $\begin{array}{l}\text { Dešinès rankos } \\
\text { tirpimas }\end{array}$ & 3 & 0,6 & 1 & 2,7 & 2 & 0,5 & 0,099 \\
\hline
\end{tabular}

5 lentelè. Atliktos intervencinès procedūros ir baigtys

\begin{tabular}{|c|c|c|c|c|c|c|c|}
\hline \multirow{2}{*}{ Požymis } & \multicolumn{2}{|c|}{$\begin{array}{c}\text { Iš viso } \\
(N=473)\end{array}$} & \multicolumn{2}{|c|}{$\begin{array}{c}\text { Iki } 55 \text { m. } \\
(N=37)\end{array}$} & \multicolumn{2}{|c|}{$\begin{array}{c}55 \mathrm{~m} . \text { ir } \\
\text { vyresnès } \\
(\mathrm{N}=\mathbf{4 3 6})\end{array}$} & \multirow[t]{2}{*}{$\mathbf{p}$} \\
\hline & $\mathbf{N}$ & proc. & $\mathbf{N}$ & proc. & $\mathbf{N}$ & proc. & \\
\hline Taikyta PKI & 362 & 76,5 & 30 & 81,1 & 332 & 76,1 & 0,497 \\
\hline $\begin{array}{l}\text { Atliktas } \\
\text { stentavimas }\end{array}$ & 336 & 71,0 & 28 & 75,7 & 308 & 70,6 & 0,517 \\
\hline $\begin{array}{l}\text { Atlikta } \\
\text { trombolizè }\end{array}$ & 47 & 9,9 & 7 & 18,9 & 40 & 9,2 & 0,057 \\
\hline $\begin{array}{l}\text { Būklè po } \\
\text { gaivinimo }\end{array}$ & 23 & 4,9 & 1 & 2,7 & 22 & 5,0 & 0,525 \\
\hline Letali baigtis & 32 & 6,8 & 0 & 0,0 & 32 & 7,3 & 0,088 \\
\hline
\end{tabular}

persirgo insultu $73(15,4 \%)$ ligonès, vyresnès dažniau negu jaunesnès. Gretutinių ir persirgtų ligų duomenys pateikiami 1 lentelèje.

Tyrimo metu trūko duomenų apie pacienčių rūkymą, kūno masès indeksą, šeiminę anamnezę, tikslų laiką nuo miokardo infarkto simptomatikos pradžios iki hospitalizavimo. Turimais duomenimis $(\mathrm{N}=88)$, rūkè $25(28,4 \%)$ gydytų moterų, iš jų < 55 m. $8(42,1 \%), \geq 55$ m. 17 (24,6\%), $(p=0,135)$. Teigiama šeiminè anamnezè nustatyta 27 
$(84,4 \%)$ pacientèms, iš jų $<55$ m. 7 (77,8\%), $\geq 55$ m. 20 $(87 \%)(\mathrm{N}=32),(\mathrm{p}=0,52)$. Kūno masès indeksas $(\mathrm{KMI})(\mathrm{N}$ $=52$ ) tarp jaunesnių moterų $30,27 \pm 6,22$, vyresnių - 32,46 $\pm 5,68$ ( $\mathrm{p}=0,739)$. Vidutinis laikas nuo miokardo infarkto simptomų pradžios iki hospitalizavimo amžiaus grupeje iki $55 \mathrm{~m}$. 5,33 $\pm 3,80$ val., $55 \mathrm{~m}$. ir vyresniu grupeje 4,19 \pm 3,13 val. $(\mathrm{N}=111),(\mathrm{p}=0,308)$.

Skausmą krūtinèje juto $415(87,7 \%)$ pacienčių, šis simptomas labiau paplitęs jaunesnių moterų grupeje 36 (97,3\%). Trečdalis tiriamujų pojūčius krūtinèje apibūdino kaip spaudimą už krūtinkaulio. Didesnių statistiškai patikimų skausmo pobūdžio skirtumų tarp amžiaus grupių nerasta ( 2 lentelè). Dažniausiai skausmas plito ị kairę ranką 74 (15,6\%), amžiaus grupejje iki $55 \mathrm{~m}$. beveik dvigubai dažniau negu daugiau kaip $55 \mathrm{~m}$. grupejje. Skausmo pli-

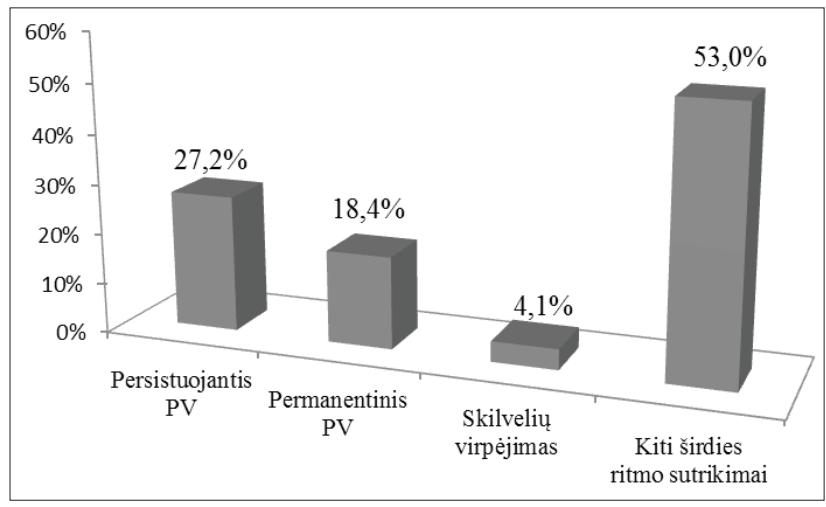

3 pav. Prieširdžių ir skilvelių virpejjimų dažnis tarp turinčiųjų širdies ritmo sutrikimų

Proc. nuo pacienčiu, turinčiu širdies ritmo sutrikimu. $P V$ - prieširdžiu virpèjimas.

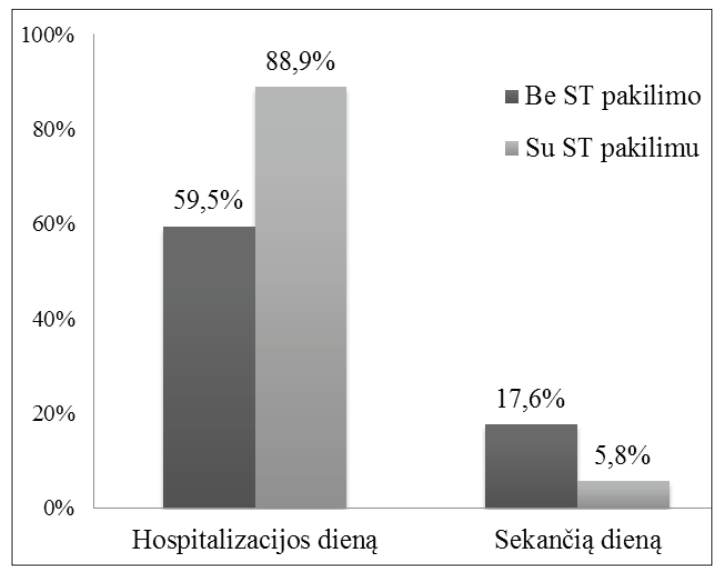

4 pav. Perkutaninès koronarinès intervencijos taikymo ūminiam miokardo infarktui laiko priklausomybè nuo ST segmento pakilimo $\mathrm{p}<0,001$ timas pagal amžiaus grupes pateikiamas 3 lentelejje. Tarp kitų üminio miokardo infarkto simptomų vyravo silpnumas 175 (37\%), kuris dvigubai dažniau pasitaikè tarp vyresnių moterų. Tarp kitų simptomų statistiškai patikimo skirtumo nenustatyta (4 lentelè).

$362(76,5 \%)$ pacientèms taikyta perkutaninè koronarinè intervencija (PKI), stentavimas atliktas 336 (71\%), trombolizè - $47(9,9 \%)$ moterims. Šios intervencinès procedūros pacientèms iki $55 \mathrm{~m}$. atliktos dažniau nei vyresnèms. Moterims, kurioms diagnozuotas STEMI, hospitalizacijos dieną perkutaninè koronarinè intervencija taikyta $185(88,9 \%)$, NSTEMI - $91(59,5 \%)(\mathrm{p}<0,001)(4$ pav.). Letali baigtis sudare $32(6,8 \%)$ visų gydytų pacienčiu. Visos mirusios pacientès buvo vyresnès nei $55 \mathrm{~m}$. (5 lentelè). Tirtoms moterims su letalia baigtimi dažniausiai nustatyta Killip IV 25 (78,1\%) (5 pav.).

\section{Rezultatų aptarimas}

Pastaruosius dešimt metų jaunų pacientų, sergančių ūminiu miokardo infarktu, hospitalizacijų dažnis nemažèja [11]. Atvirkščiai, pastebima sergamumo didejjimo tendencija.

Nustatyta, kad tarp jaunų moterų (iki $55 \mathrm{~m}$.), sergančių ūminiu miokardo infarktu, gretutinių ligų paplitimas didesnis negu tarp vyrų [11]. Moterys $<50 \mathrm{~m}$. išgyvenusios po ūminio miokardo infarkto dažniau serga cukriniu diabetu ir hipertenzija negu to paties amžiaus vyrai. Šie rezultatai pabrèžia nuolatini cukrinio diabeto prevencijos ir kontrolès poreikị jauniems pacientams, ypač moterims $[5,12]$. Remiantis tyrimo rezultatais, $23 \%$ gydytų pacienčių sirgo cukriniu diabetu. Jaunesnėms moterims dažniau nustatytas I tipo cukrinis diabetas, palyginus su vyresnių pacienčiu grupe, o $>55 \mathrm{~m}$. moterims dažniau diagnozuotas II tipo cukrinis diabetas. Tuo tarpu 91,1\% pacienčiu sirgo pirmine arterine hipertenzija, vyresnès moterys dažniau negu jaunesnès.

Tarp jaunų pacientų su teigiama šeimine anamneze la-

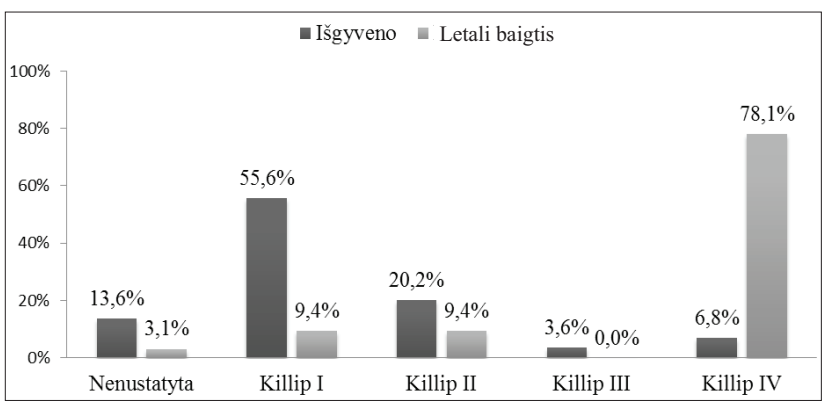

5 pav. Letalių baigčių priklausomybė nuo Killip laipsnio $\mathrm{p}<0,001$ 
biau paplitusios kardiovaskulinès ligos (40\%), palyginus su neigiama šeimine anamneze (30\%). Tai susiję su padidejjusia miokardo infarkto rizika. Otaki ir kt. 2013 m. tyrimo duomenimis, teigiama šeiminè anamnezè tarp jaunu pacientu yra stipriausias miokardo infarkto prognostinis veiksnys, palyginti su kitais kardiovaskulinių ligų rizikos veiksniais [13].

Kitas svarbus rizikos veiksnys - rūkymas, kuris turi ypač žalingą poveikị jaunoms moterims, $60 \%$ padidina išeminès širdies ligos riziką, palyginus su vyrais [14]. Tai įrodo 42,1\% rūkymo paplitimas tarp jaunesnių nei $55 \mathrm{~m}$. pacienčių, palyginus su $24,6 \%$ vyresnių moterų grupe.

Krūtinès skausmas yra dažniausias miokardo infarkto simptomas. 1 iš 5 jaunesnių negu $55 \mathrm{~m}$. moterų nepatiria krūtinès skausmo miokardo infarkto metu. Taip pat moterys rečiau junta krūtinès skausmus negu vyrai [15]. Mūsų tyrimo duomenimis, skausmą krūtinèje juto $87,7 \%$ pacienčių ir šis simptomas vyravo jaunesnių moterų grupejje (97,3\%). Canto ir kt. $1994-2006$ m. Nacionalinio miokardo infarkto registro pacientų tyrimo duomenimis, krūtinès skausmo nebuvimas susijęs su diabetu ir nepriklauso nuo amžiaus ir lyties [16].

Moterims būdinga didesnè miokardo infarkto simptomu ịvairovè negu vyrams. Tarp tirtų norvegų moterų ir vyrų iki $65 \mathrm{~m}$. amžiaus, pirmą kartą sirgusių ūminiu miokardo infarktu, nustatyta, kad vyrai dažniau nei moterys mane, kad jų simptomatika kardialinès kilmès [17]. Daugelis moterų nesugeba susieti jų simptomatikos su širdies ligomis, nes daug pasireiškiančių simptomų miokardo infarkto metu yra atipiniai. Tai dažnai lemia kreipimosi ị gydytojus atidèliojimą [18]. Pagal žinomą tikslų laiką nuo miokardo infarkto simptomų pradžios iki hospitalizavimo, pacientès iki $55 \mathrm{~m}$. delsè kreiptis ị gydymo įstaigą vidutiniškai 1 valanda ilgiau $(5,33 \pm 3,80 \mathrm{val}$.) negu vyresnès $(4,19 \pm 3,13 \mathrm{val})$.

Jaunos moterys, sergančios miokardo infarktu, turi didesnę mirštamumo riziką negu likusi populiacija. Didesnè atipinių simptomų tikimybe jaunoms moterims gali lemti didesni jų mirties dažnį [16]. Pastaraji dešimtmetị moterų mirtingumas nuo miokardo infarkto dideja. $2001 \mathrm{~m}$. moterys sudare $41,97 \%$ mirčiu nuo miokardo infarkto atvejų, o $2010 \mathrm{~m}$. rodiklis išaugo iki 48,47\% [6]. Šio tyrimo duomenimis, letali baigtis sudare $32(6,8 \%)$ visų gydytu pacienčių. Visos mirusios pacientès buvo vyresnès nei $55 \mathrm{~m}$. Pacientėms su letalia baigtimi Killip IV nustatyta dažniausiai 25 (78,1\%). Aukšta Killip klasė yra nepriklausomas miokardo infarkto mirtingumo prognozès rodiklis [19].

Remiantis Virmani ir kt. analizès duomenimis, manoma, kad skiriasi vyresnio amžiaus moterų staigios koronarinès mirties mechanizmai, lyginant su vidutinio amžiaus arba prieš menopauzę moterimis. Nustatyta, kad rizikos veiksniai gali daryti didelę įtaką šiose pacientų grupėse. Tarp jaunų moterų, kurios miršta nuo vainikinių arterijų trombozès, dažnas rizikos veiksnys yra rūkymas, būdingos aterosklerozinių plokštelių erozijos ir santykinai mažas vainikinių arterijų susiaurejimas. Tuo tarpu vyresnio amžiaus moterys, kurios miršta dèl širdies vainikinių arterijų trombozès, dažnai turi aukštą cholesterolio lygi kraujyje ir joms būdingas vẻlesnis aterosklerozinių plokštelių plyšimas su santykinai dideliu vainikiniu kraujagysliu susiaurèjimu [20]. Taip pat neaterosklerozinè vainikinių arterijų liga nèra reta tarp jaunų moterų (50 m. ir jaunesnių), kurioms atlikta vainikinių arterijų angiografija ir yra svarbi miokardo infarkto priežastis, sudaranti apie 30\% [21].

\section{Išvados}

Nedidelè pacienčių dalis serga ūminiu miokardo infarktu iki $55 \mathrm{~m}$. Pastebimi gretutinių ligų ir rizikos veiksnių skirtumai pacienčių amžiaus grupėse: vyresnès moterys ( $\geq$ $55 \mathrm{~m}$.), gydomos dẻl ūminio miokardo infarkto, dažniau serga II laipsnio PAH, turi širdies ritmo sutrikimų, ankščiau persirgusios miokardo infarktu, tačiau jaunesnès dažniau serga I tipo cukriniu diabetu. Simptomatikos pasireiškimas skiriasi nežymiai: vyresnès dažniau jaučia silpnumą, jaunesnèms pacientėms būdingesnis skausmo plitimas ị kairę ranką, jos ilgiau delsia kreiptis ị gydymo ịstaigą. Didesni rizikos veiksnių, simptomatikos ir baigčių skirtumai pastebimi tarp lyčių. Nustatyta Killip IV lemia didesnị letalumą sergant ūminiu miokardo infarktu.

\section{Literatūra}

1. Vaccarino V, Badimon L, Corti R, de Wit C, Dorobantu $\mathrm{M}$, Hall A. et al. Ischaemic heart disease in women: are there sex differences in pathophysiology and risk factors? Cardiovasc Res. Apr 1, 2011; 90(1): 9-17.

2. Mirties priežasčių registras. Mirties priežastys 2013. Higienos instituto Sveikatos informavimo centras. ISSN 1392-9186.

3. Nichols M, Townsend N, Scarborough P, Rayner M, Leal J, Luengo-Fernandez R. et al. European Cardiovascular Disease Statistics. 2012 edition. ISBN 978-2-9537898-1-2.

4. Rinkūnienė E., Petrulionienė Ž., Zdanevičiūtè I., Dženkevičiūtė V. Mirtingumo nuo širdies ir kraujagyslių ligų tendencijos Lietuvoje ir Europos Sajungos šalyse. Medicinos teorija ir praktika, 2013;19 (2):130-136.

5. Rastenytė D, Jančaitytè L. Sex differences in one-year mortality after a first-ever myocardial infarction. Medicina (Kaunas), 2005; 41(9).

6. Šerpytis P., Ciparytė L., Gaidelytè R., Gurevičius R. Moterys ir kardiovaskulinès ligos. Visuomenès sveikata, 2011; 21(5): 38-43.

7. Yang X, Reckelhoff JF. Estrogen, hormonal replacement therapy and cardiovascular disease. Curr Opin Nephrol Hypertens. Mar 2011; 20(2): 133-138. 
8. De Peretti C, Chin F, Tuppin P, Danchin N. Personnes hospitalisées pour infarctus du myocardeen France: tendances 20022008. BEH. 2012;41:459-465.

9. Izadnegahdar M, Singer J, Lee MK, Gao M, Thompson CR, Kopec J. et al. Do Younger Women Fare Worse? Sex Differences in Acute Myocardial Infarction Hospitalization and Early Mortality Rates Over Ten Years. J Womens Health (Larchmt). 2014 Jan;23(1):10-7.

10. Vaccarino V, Badimon L, Corti R, de Wit C, Dorobantu M, Manfrini O. et al. Presentation, management, and outcomes of ischaemic heart disease in women. Nat Rev Cardiol 2013 Sep;10(9):508-18.

11. Gupta A, Wang Y, Spertus JA, Geda M, Lorenze N, NkondePrice C. et al. Trends in acute myocardial infarction in young patients and differences by sex and race, 2001 to 2010. J Am Coll Cardiol 2014 Jul 29;64(4):337-45.

12. Egiziano G, Akhtari S, Pilote L, Daskalopoulou SS; genesis (GENdEr and Sex Determinants of Cardiovascular Disease) Investigators. Sex differences in young patients with acute myocardial infarction. Diabet Med 2013 Mar;30(3):e108-14.

13. Otaki Y, Gransar H, Berman DS, Cheng VY, Dey D, Lin FY. et al. Impact of family history of coronary artery disease in young individuals (from the CONFIRM registry). Am J Cardiol 2013 Apr 15;111(8):1081-6.

14. Prescott E, Hippe M, Schnohr P, Hein HO, Vestbo J. Smoking and risk of myocardial infarction in women and men: longitudinal population study. BMJ 1998;316:1043-1047.

15. Khan NA, Daskalopoulou SS, Karp I, Eisenberg MJ, Pelletier R, Tsadok MA. et al. Sex Differences in Acute Coronary Syndrome Symptom Presentation in Young Patients. AMA Intern Med 2013;173(20):1863-1871.

16. Canto JG, Rogers WJ, Goldberg RJ, Peterson ED, Wenger NK, Vaccarino V. et al. Association of Age and Sex With Myocardial Infarction Symptom Presentation and In-Hospital Mortality. JAMA, 2012 Feb 22;307(8):813-22.

17. Løvlien M, Schei B, Gjengedal E. Are there gender differences related to symptoms of acute myocardial infarction? A Norwegian perspective. Prog Cardiovasc Nurs 2006 Winter; 21(1):14-9.

18. Miracle VA. Coronary Artery Disease in Women: The Myth Still Exists. Dimens Crit Care Nurs 2006 Sep-Oct;25(5):209-15.

19. El-Menyar A, Zubaid M, AlMahmeed W, Sulaiman K, AlNabti A, Singh R. et al. Killip classification in patients with acute coronary syndrome: insight from a multicenter registry. Am J Emerg Med 2012 Jan;30(1):97-103.

20. Virmani R, Burke AP, Farb A, Kolodgie FD. Pathology of the vulnerable plaque. J Am Coll Cardiol 2006;47(8):(suppl) C13-C18.

21. Saw J, Aymong E, Mancini GB, Sedlak T, Starovoytov A, Ricci D. Nonatherosclerotic coronary artery disease in young women. Can J Cardiol 2014 Jul;30(7):814-9.

\section{CLINICAL SYMPTOMS OF MYOCARDIAL INFARC- TION AND ITS OUTCOMES FOR WOMEN \\ Ž. Petrulionienė, P. Šerpytis, D. Jančauskaitė, \\ U. Gargalskaitė, B. Brazauskaitė, A. Strazdas}

Key words: acute myocardial infarction, risk factors, women, symptoms.

Summary

Objective. The aim of the present study was to compare differences of symptoms, comorbidities, risk factors and outcomes in younger (up to 55 years-old) and older (over 55 years-old) women with acute myocardial infarction.

Materials and methods. In this retrospective study we analised 473 cases of women with acute myocardial infarction treated in 2012. Patients were divided into two groups according to their age: group I (up to 55 years) and group II (older than 55 years). The first group included 37 patients while the second group - 436 patients.

Results. The average age of patients was $72,3 \pm 11,07 \mathrm{~m}$. Myocardial infarction with ST elevation were diagnosed to $54,3 \%$, of wich Q+ 70,4\%, Q- 29,6\% ( $<<0,001)$, non-ST elevation 45,7\%, of wich $\mathrm{Q}+6,5 \%$, Q- 93,5\% ( $<<0,001)$, no statistically significant difference was observed between the groups. 73\% women in group I had primary arterial hypertension (I grade $2,7 \%$, II 59,5\%, III $10,8 \%$ ), in the second group - $92,7 \%$ (I grade $0,7 \%$, II $86 \%$, III $6 \%),(\mathrm{p}<0,001)$. Moreover, $13,5 \%$ patients in group I had diabetes $(5,4 \%$ of type I, $8,1 \%$ of type II), in the group II $23,9 \%$ $(0,3 \%$ of type I, $23,6 \%$ of type II), $(\mathrm{p}<0,001)$. Heart rhythm disorders were more often in women over 55 years-old $(32,8 \%)$, $(\mathrm{p}=0,006)$. Among these patients, persistent atrial fibrilation were identified in $27,2 \%$, permanent atrial fibrilation in $18,4 \%$, ventricular fibrilation in 4,1\% patients (all p < 0,001). 5,4\% women in younger group had previously experienced myocardial infarction while in older group - $20 \%(p=0,03)$. The spread of the pain to left hand was more common in the group of younger patients $(27 \%)$ $(\mathrm{p}=0,047)$. Futhermore, in group I 18,9\% felt weakness, while in group II - 38,5\% $(\mathrm{p}=0,018)$. Fatal outcomes were observed in $6,8 \%$ patients, all of them were older than 55 years. Among patients with fatal outcomes Killip IV were found to $78,1 \%$ patients $(\mathrm{p}<0,001)$.

Conclusions. Older women ( $\geq 55$ years-old) treated for acute myocardial infarction more often had the grade II of primary arterial hypertension, heart rhythm disorder, previously experienced mycardial infarction and felt weakness. Younger patients (below 55 years old) had type I diabetes more often and were characterized by pain spreading to the left arm. Determined Killip IV leaded to increased lethality.

Correspondence to: zaneta.petrulioniene@santa.1t

Gauta 2014-10-30 